\title{
IMPLEMENTASI PEMBELAJARAN TEMATIK PADA MASA PANDEMI COVID-19 DI KELAS II MI AS-SALAM O’O DOMPU
}

\author{
Akhmad Asyari ${ }^{1}$, Diah Cahyani Putri ${ }^{2}$ \\ ${ }^{1,2}$ Universitas Islam Negeri Mataram \\ 1akhmadasyari@uinmataram.ac.id \\ 22diahcahyani@gmail.com
}

\begin{abstract}
Abstrak: Penelitian ini bertujuan untuk mengeksplorasi secara mendalam tentang implementasi, tantangan dan upaya guru mengatasi berbagai persoalan dalam pembelajaran tematik pada Kelas II b MI As-Salam O'o Dompu. Penelitian ini menggunakan penelitian deskriftip dimana pengambilan sampel dilakukan dengan purposive dan snowball. Adapun Teknik pengumpulan data menggunakan wawancara, observasi dan dokumentasi. Hasil penelitian menggambarkan bahwa impelementasi pembelajaran tematik dengan mempedomani RPP dan mengacu pada tema sebagaimana kondisi normal. Adapun persoalan yang dihadapi dalam penerapan pembelajaran tematik diantaranya difaktori oleh faktor kesiapan dan pemahaman guru tentang perencanaan, pelaksanaan, dan evaluasinya. Adapun upaya guru mengatasi berbagai persoalan di atas yaitu dengan diskusi rutin tentang pembelajaran tematik kurikulum 2013 serta mendalami dan memahami secara detail tentang komponen penting dalam perencanaan, pelaksanaan dan evaluasi serta seefektif mungkin memanfaatkan lingkungan sekitar sebagai sumber belajar.
\end{abstract}

Kata kunci: pembelajaran, tematik, kurikulum 2013, perencanaan, pelaksanaan, evaluasi

Abstrack: This study aims to explore in depth about the implementation, challenges and efforts of teachers to overcome various problems in thematic learning in Islamic primary school. This research uses descriptive research where sampling is done by purposive and snowball. The data collection techniques using interviews, observation and documentation. The results of the study describe that the implementation of thematic learning is guided by the lesson plans and refers to the theme as normal conditions. The problems faced in the application of thematic learning are factored in by factors of readiness and teacher understanding of planning, implementation, and evaluation. The teacher's efforts to overcome the various problems above are through regular discussions about thematic learning of the 2013 curriculum as well as exploring and understanding in detail about the important components in planning, implementing and evaluating as well as effectively utilizing the surrounding environment as a learning resource.

Keywords: learning, thematic, k13 curriculum, planning, acting, evaluation 


\section{PENDAHULUAN}

Salah satu ahli yaitu Dahama \& Bhatnagar mengatakan bahwa definisi pendidikan menurutnya adalah suatu proses membawa perubahan yang diinginkan dalam perilaku manusia. Dapat juga didefinisikan sebagai proses perolehan pengetahuan dan kebiasaan-kebiasaan melalui pembelajaran atau studi. ${ }^{1}$ Dalam UU No.20 tahun 2013 tentang sistem Pendidikan Nasional pada Pasal 1 ayat 1, yang menjelaskan tentang pengertian pendidikan bahwa: Pendidikan adalah usaha sadar dan terencana untuk mewujudkan belajar dan proses pembelajaran agar peserta didik secara aktif mengembangkan potensi dirinya untuk memilih kekuatan spiritual keagamaan, pendidikan, kecerdasan, akhlak mulia, serta keterampilan yang di perlukan dirinya dan masyarakat, bangsa dan negara. ${ }^{2}$

Pendidikan selalu dapat dibedakan menjadi teori dan praktek, karena pendidikan suatu pengetahuan tentang makna dan bagaimana seyogyanya pendidikan dilaksanakan, sedangkan praktek adalah tentang pelaksanaan pendidikan secara konkretnya (nyata). ${ }^{3}$ Dalam arti sederhana pendidikan sering diartikan sebagai usaha manusia untuk membina kepribadiannya sesuai dengan nilai-nilai di dalam masyarakat dan kebudayaan. Dalam berkembangnya, istilah pendidikan berarti bimbingan atau pertolongan yang diberikan dengan sengaja oleh orang dewasa agar menjadi dewasa. Selanjutnya pendidikan sering diartikan sebagai usaha yang dijalankan oleh seseorang atau sekelompok orang lain agar menjadi dewasa atau mecapai tingkat hidup atau penghidupan yang lebih tinggi dalam arti mental. Dan nyatanya pendidikan sekarang mengalami perkembangan meskipun secara essensial tidak jauh berbeda. ${ }^{4}$

Dunia pendidikan adalah sesuatu yang sangat penting bagi seorang manusia, karena pendidikan membuat manusia berkembang lebih baik kedepannya. Tidak ada hal yang tiak berkembang begitupun manusia, tidak ada manusia yang hanya berada pada titik yang sama tidak memiliki perkembangan yang maju dalam perkembangan zaman, dan semuanya bermula pada sebuah pendidikan. Suatu proses pendidikan tidak lepas dari sebuah pembelajaran. Pembelajaran merupakan suatu sistem atau proses membelajarkan subjek didik atau pembelajaran yang direncanakan atau didesain, dilaksanakan dan dievaluasi secara sistematis agar pembelajaran dapat mencapai tujuan-tujuan pembelajaran secara efektif dan efisien. Dengan demikian, jika pembelajaran dipandang sebagai suatu sistem, berarti pembelajaran terdiri atas sejumlah komponen yang terorganisasi antara tujuan pembelajaran, materi pembelajaran, strategi dan metode pembelajaran, media pembelajaran, perorganisasian kelas, evaluasi pembelajaran dan tindak lanjut pembelajaran. Sebaliknya, jika pembelajaran dipandang sebagai suatu proses maka pembelajaran merupakan rangkaian upaya atau kegiatan guru dalam rangka membuat peserta didik

\footnotetext{
${ }^{1}$ Ruslam Ahmadi, Pengantar Pendidikan, (Yogyakarta : Ar-Ruzz Media, 2016), hlm 33

2 Depdiknas, Undang-undang Sistem Pendidikan, (Jakarta: Eka Jaya, 2003)

3 Imam Barnadid, Dasar-Dasar Pendidikan, (Bogor : Galia Indonesia), hlm. 8.

${ }^{4}$ Hasbullah, Dasar-Dasar Ilmu Pendidikan (Edisi Revisi), (Jakarta : Raja Grafindo Persada, 2012),
} hlm.1-2 
belajar. Pembelajaran merupakan suatu sistem maka dibutuhkan peran dari masingmasing komponen agar dapat mencapai tujuan yang telah ditetapkan. ${ }^{5}$

Perubahan atau perkembangan pendidikan adalah hal yang memang seharusnya terjadi sejalan dengan perubahan budaya kehidupan manusia. Perubahan dalam arti perbaikan pendidikan pada semua tingkat perlu terus menerus dikakukan sebagai antisipasi kepentingan masa depan dengan tututan masyarakat modern. Hal ini tentu saja menyangkut berbagai bidang, tidak terkecuali bidang pendidikan. Komponen yang melekat pada pendidikan diantaranya adalah kurikulum. ${ }^{6}$ Sebuah pendidikan tentunya memiliki rancangan pembelajaran yang nantinya akan diberikan kepada peserta didik atau sering disebut kurikulum. Kurikulum adalah seperangkat rencana dan peraturan mengenai isi dan bahan pelajaran serta cara yang di gunakan sebagai pedoman penyelenggaraan kegiatan belajar mengajar. Hubungan antar kurikulum dengan pembelajaran saling terkait, pengembangan kurikulum hendaknya memerhatikan prinsip-prinsip kegiatan belajar, dan sebaiknya perencanaan kegiatan pengajaran harus memperhatikan gambaran menyeluruh yang tercakup dalam kurikulum. Kurikulum menempati posisi yang sangat menentukan dalam sebuah pendidikan. Ibarat tubuh, kurikulum merupakan jantungnya pendidikan. Di Indonesia sudah diterapkan kurikulum 2013. Perkembangan dalam kurikulum 2013 ini terletak pada pengemasan yang memperjelas prosesnya melalui pembelajaran tematik. Pembelajaran tematik dimaknai sebagai pembelajaran yang dirancang berdasarkan tema-tema tertentu schingga dapat memberikan pengalaman terhadap siswa. Dalam pembahasannya tema itu ditinjau dari berbagai mata pelajaran. Tematik adalah lambang dari seluruh bahasa pelajaran yang memfalitasi siswa untuk produktif menjawab pertanyaan yang dimunculkan sendiri dan memuaskan rasa ingin tahu dengan penghayatan secara alamiah tentang sekitar mereka. ${ }^{7}$

Namun melihat kondisi negara Indonesia yang masih belum aman dari virus Covid-19 pemerintah Indonesia pada tanggal 24 Maret 2020 melalui Menteri Pendidikan dan Kebudayaan Republik Indonesia mengeluarkan Surat Edaran Nomor 4 Tahun 2020 tentang pelaksanaan kebijakan pendidikan dalam masa darurat penyebaran Covid-19, pemerintah mengeluarkan surat edaran tersebut agar proses belajar dapat dilaksanakan di rumah atau melalui pembelajaran daring guna untuk mencegah penyebaran wabah tersebut. Karena dampak penyebaran virus Covid-19 sangat mengganggu dunia pendidikan di Indonesia.

Menindak lanjuti edaran surat edaran dari pemerintah pusat dan provinsi ${ }^{8}$ mengenai pembelajaran daring yang telah diterapkan dikabupaten dompu selama 7 Bulan sejak surat edaran provinsi tersebut dikeluarkan. Hasil evaluasi dan

5 Erwin Widiosworo, 19 Kiat Sukeses Motivasi Belajar Peserta Didik, (Yogyakarta: Ar-Ruzz Media, 2015), hlm 19.

6 Sofian Amri, Pengembangan Dan Model Pembelajaran Dalam Kurikulum 2013, Jakarta: Prestasi Putrakarya, 2013), hlm 1

7 Trianto, Pengembangan Model Pembelajaran Tematik, (Jakarta: Prestasi Pustakakarya, 2010), hlm. 78-79

8 Menteri Pendidikan dan Kebudayaan Republik Indonesia Nomor : 4 Tahun 2020 tanggal 24 Maret 2020 tentang pelaksanaan kebijakan pendidikan dalam masa darurat penyebaran Coronavirus Disease (Covid-19), surat edaran gubernur Nusa Tengaara Barat Nomor : 180/136/Kum tanggal 26 Maret 2020 tentang Pelaksanaan Kebijakan Dalam Masa Darurat penyebaran Covid-19. 
pemantauan terhadap sistem pembelajaran daring dikabupaten dompu kurang efektif yang disebabkan kendala teknis sebagai berikut: 1) Masih adanya beberapa wilayah yang belum terjangkau oleh Aksebilitas Telekomunikasi, 2) Masih terdapatnya siswa yang belum memiliki HP Android, 3) Terkendala pada ekonomi masyarakat (orang tua murid) untuk membeli paket internet, dan 4) Kemampuan siswa terutama siswa sekolah dasar dan siswa yang berada pada daerah terpencil berkaitan dengan teknis pelaksanaan secara daring. ${ }^{9}$

Meninjau hasil evaluasi permasalahan tersebut, Bupati Dompu bersama dengan Dinas Pendidikan Pemuda dan Olahraga Kabupaten Dompu mengeluarkan Surat Edaran terbaru Nomor 360/90/BPBD/III/2021 tentang "Pelaksanaan kegiatan pembelajaran tatap muka tahun ajaran 2020/2021 di masa pandemi Covid-19 dikabupaten dompu". Bupati Dompu mengeluarkan surat edaran ini dengan memperhatikan kondisi kabupaten dompu yang berada pada Zona Orange (Zona Resiko Sedang). Pembelajaran tatap muka pada masa pandemi ini dilakukan dengan sistem shift (bergantian). Kembalinya kegiatan pembelajaran tatap muka ini tetap memperhatikan protokol kesehatan, seperti memakai masker, sekolah menyediakan tempat cuci tangan dan juga handsainitaizer.

Berdasarkan latar belakang masalah diatas peneliti tertarik meneliti terkait kegiatan pembelajaran tematik pda masa pandemi Covid-19, khususnya Kelas II b di MI As-Salam O’o Dompu. Maka peneliti mengambil judul penelitian "Implementasi Pembelajaran Tematik Pada Masa Pandemi Covid-19 di Kelas II MI As-Salam O'o Dompu Tahun Pelajaran 2020/2021.

\section{METODE}

Penelitian ini menggunakan penelitian kualitatif deskriptif. dimana peneliti adalah sebagai instrumen kunci. Pengambilan dan pemilihan sampel penelitian dilakukan secara purposive dan snowball. Adapun teknik pengumpulan data menggunakan trianggulasi yaitu pemaduan berbagai metode pengumpulan data yaitu observasi, wawancara dan dokumentasi. Sedangkan analisis data bersifat induktif/kualitatif, dan hasil penelitian kualitatif lebih menekankan makna daripada generalisasi. ${ }^{10}$ Teknik analisis data menggunakan miles and Huberman yaitu data reduction, data display, dan penarikan kesimpulan.

\section{HASIL DAN PEMBAHASAN}

Adapun temuan hasil penelitian pembelajaran tematik pada masa pandemic covid 19 di kelas IIb MIN As-Salam O'o Dompu memuat perencanaan, pelaksanaan, pengelolaan kelas dan evaluasi. Lebih jelasnya diuraikan sebagai berikut:

\section{Perencanaan Pembelajaran Tematik Kelas II b MIN As-Salam O’o Dompu}

9 Surat Edaran Nomor 360/90/BPBD/III/2021 tentang "Pelaksanaan kegiatan tatap muka tahun ajaran 2020/2021 di masa pandemic covid-19 di Kabupaten Dompu"

10 Sugiyono, Metode Penelitian Pendidikan Pendekatan Kualitatif, Kuantitatif, Dan R\&D, (Bandung: Alfabeta, 2015), hlm. 15. 
Penerapan pembelajaran tematik dilakukan dengan mengintegrasikan berbagai mata pelajaran. Namun prakteknya dilapanganlah yang membedakannya. Kepala Madrasah MI As-Salam O’o Dompu mengatakan bahwa:

"implementasi pembelajaran tematik pada Covid-19 ini sebenarnya tidak jauh berbeda dengan sebelum covid, akan tetapi yang menjadi perbedaannya ialah waktu pembelajaran pada masa Covid-19 ini kami persingkat. Sekarang pembelajaran menggunakan sitem shift (bergantian) untuk kelas I, II, dan III pelaksanaan pembelajarannya hari Senin, Selasa, dan Rabu, sedangkan untuk kelas IV, V, dan VI pelaksanaan pembelajarannya hari Kamis, Jum'at dan Sabtu dan pembelajaran dimulai dari pukul 07.45-10.50 WITA."

Dalam kegiatan belajar kurikulum dan program pengajaran adalah diberikan kebebasan untuk mengembangkan kurikulum yang sudah ditetapkan oleh pemerintah yang disesuaikan dengan situasi dan kondisi sekolah berada. Namun tidak diperbolehkan untuk mengurangi isi kurikulum yang sudah ditetapkan secara Nasional yang telah dikembangkan oleh pemerintah pusat.

Selain itu diberikan kebebasan untuk mengembangkan kurikulum. Pada proses perencanaan pembelajaran tematik pada Kelas II b, proses perencanaannya sesuai dengan guru kelas yang akan melakukan proses pembelajaran tematik. Seperti halnya yang di ungkapkan oleh kepala madrasahnya :

"Bahwa dalam perencanaan sebelum melakukan pembelejaran tematik guru menyiapkan perangkat pembelajaran yang sesuai dengan tema dalam pembuatan RPP dan Silabus, di dalam perangkat pembelajaran itu guru harus pintar dan kreatif dalam memilih media, strategi, metode agar pembelajaran berhasil sesuai yang saya inginkan serta siswa pun faham akan yang guru sampaikan". ${ }^{11}$

\section{Pelaksanaan Pembelajaran Tematik di Kelas II b MI As-Salam O’o Dompu}

Pembelajaran tematik di As-Salam O'o Dompu sudah menerapkan kurikulum 2013, tetapi tidak semua kelas menggunakan kurikulum 2013. Melainkan hanya kelas I,II, dan III saja yang menerepkan kurikulum 2013, dan untuk kelas IV,V dan VI masih menggunakan kurikum yang lama yaitu KTSP. Seperti yang diungkapkan oleh kepala madrasah Bapak sebagai berikut :

"Untuk penerapan pembelajaran tematik di MI As-Salam ini masih menggunakan dua kurikulum yaitu pada kelas I,II,III menggunakan kurikulum 2013 dan pada kelas IV,V,VI mengunakan kurikulum KTSP. Sebenarnya pelaksanan kurikulum 2013 masih perlu pemahaman agar penerapan pembelajaran tematik dapat berjalan sesuai dengan tujuan yang ingin diharapkan"12

11 Wawancara dengan bapak Kepala Madrasah MI As-salam OO Dompu, tanggal 17 Maret

12 Wawancara dengan Kepala Madrasah MI As-Salam OO Dompu pada tanggal 17 Maret 
Kurikulum 2013 dikemas dalam bentuk tema-tema atau yang lebih dikenal dengan pembelajaran tematik. MI As-Salam O'o Dompu masih kaku dalam melaksanakan pembelajaran tematik. Hal tersebut dibuktikan dengan kurangnya media pembelajaran dan alat peraga. Seperti yang diungkapkan oleh kepala madrasah

"Di MI As-Salam ini sendiri banyak sekali media pembelajaran yang kurang seperti buku, LCD dll serta alat peraga yang tidak ada, tetapi itu semua bukan menjadi penghalang, saya menghimbau kepada seluruh guru agar bisa mengunakan beberapa metode pembelajaran agar peserta didik mudah memahami pembelajaran walaupun banyak media pembelajaran yang kurang" 13

Proses ini diperlukan agar kemampuan guru untuk mengelola suasana belajar menjadi aktif, interaktif dan menyenangkan, sehingga siswa menjadi tertarik dan termotivasi dalam belajar. Untuk membenarkan apa yang diungkapkan oleh kepala madrasah dan para guru kelas, terkait pelaksanaan pembelajaran tematik di dalam kelas, maka peneliti melakukan observasi ikut masuk kelas untuk mengawasi dan memperhatikan jalannya proses pembelajaran oleh guru Kelas II b pada tanggal 19 maret 2021 tepat pukul 07.45-10.50 WITA peneliti sudah dikelas untuk mengikuti proses pembelajaran dari awal sampai akhir pembelajaran.

\section{Problematika Guru Dalam Mengimplementasikan Pembelajaran Termatik di Kelas II b MI As-Salam O’O Dompu}

Penerapan pembelajaran tematik pada Kelas II b MI As-Salam O'o Dompu tidak begitu saja dapat diterapkan, terdapat berbagai persoalan yang dihadapi, sebagaimana diungkapkan oleh guru Kelas II b sebagai berikut:

"masalahnya adalah para guru kelas awal masih merasakan kesulitan dalam pembuatan perangkat pembelajaran tematik, tidak tersedianya bahan ajar terutama buku ajar bersifat tematik yang memadai, pengolaan evaluasi pada pembelajaran tematik bentuk pelaporan hasil penilaian pembelajaran tematik murni masih bersifat per/mata pelajaran belum terstandar tematik. Ditambah covid ini permasalahan baru muncul seperti kami para guru harus bisa menyesuaikan waktu mengajar"14

\section{Upaya Guru Dalam Mengatasi Problematika Pembelajaran Tematik}

Untuk mengatasi berbagai persoalan yang dihadapi guru dalam pembelajaran tematik diungkapkan oleh kepala madrasah yang mengatakan bahwa:

"ketika masa pandemi Covid-19 ini saya menghimbau para guru untuk bisa menyesuaikan waktu pembelajaran yang ada, selain itu juga pelaksanaan pembelajaran tematik guru memang dituntut untuk benar-benar memahami pembelajaran temetik secara konseptual maupun secara praktikal dengan sering diadakan pendidikan dan pelatihan atau workshop yang disesuikan dengan kebutuhan para guru, diskusi dengan para guru kelas serta mengadakan pembahasan dalam kelompok kerja guru (KKG) baik di MI,

\footnotetext{
13 Ibid

${ }^{14}$ Wawancara guru kelas II, tanggal 18 Maret 2021
} 
tapi kembali lagi karna kondisi masih dalam keadaan seperti ini kegiatan tersebut terhambat. perlu di upayakan buku penunjang khusus yang memuat bahan ajar yang sesuai dengan pembelajaran tematik. Terkait dengan laporan penilaian dalam pembelajaran tematik seharusnya disajikan dalam bentuk yang lebih komunikatif sehingga tingkat kemajuan belajar siswa mudah terbaca dan dapat dipahami oleh siswa dan orang tua"15

Senada dengan pendapat di atas, guru Kelas II b juga membagi pandangan tentang solusi yang dilakukan sebagai berikut:

"menurut saya, ketika pembelajaran tematik ingin diberlakukan pada kelas I dan II seharusnya juga menyediakan penunjang dalam pembelajaran tematik seperti adanya bahab ajar khusus yang memuat tematik juga dari segi laporan hasil penilaian seharusnya disajikan dalam bentuk yang mudah dipahami oleh siswa dan orang tau sehingga siswa dan orang tua mengerti sejauh mana tingkat keberhasilan belajarnya, solusi lainnya adalah selain pembelajaran di kelas kita usahakan anak-anak juga di ajak untuk memenfaatkan media yang ada di luar kelas. "16

Hasil wawancara di atas didukung juga oleh hasil observasi bahwa upaya yang dilakukan guru kelas dalam mengatasi problematika tersebut sebagaian besar belum terlaksana secara maksimal, seperti pertemuan dengan teman sejawat pernah terlaksana namun pertemuan tersebut belum efektif membahas secara keseluruhan yang harus dilakukan guru ketika menghadapi permasalahan dalam pembelajaran tematik. Hal ini harus lebih banyak lagi dilakukan penjadwalan pertemuan tersebut. Pertemuan KKG juga yang dibahas oleh kepala sekolah namun belum intensitas pembahasan pembelajaran tematik masih belum. Ada beberapa guru kelas yang mengikuti keegiatan tersebut, namun tidak semua guru mengikuti karena untuk mengikuti kegiatan tersebut guru harus memiliki dana sendiri sehingga para guru merasa keberatan dengan hal ini menjadi PR bagi kepala madrasah agar seluruh guru kelas bisa mengikuti pelatihan tersebut atau mencari solusi terbaik untuk meningkatkan kualitas pendidikan guru kelas terutama pembelajaran tematik. Bentuk laporan penilaian adalah salah satu problem yang paling besar dihadapi oleh guru kelas, karena materi tematik yang diberikan tidak sesuai dengan soal yang diberikan guru sehingga dalam bentuk format penilaian pembelajaran tematik ini perlu lagi ditingkat terlebih dalam penulisan rapot tematik yang memiliki formula tersendiri dan sebagaian guru tidak memilikinya, oleh sebab itu guru kelas di MI As-Salam O’O Dompu sepakat agar saling memberikan bantuan dalam memecahkan permasalahan dalam penilaian tematik ini.

\section{Implementasi Pembelajaran Tematik di MI As-Salam O’o Dompu}

Implementasi pembelajaran tematik dilakukan untuk meningkatkan efisiensi dan efektivitas layanan dan pengembangan sebagai konsekuensi dari suatu inovasi

15 Wawancara dengan Kepala Madrasah MI As-Salam OO Dompu pada tanggal 17 Maret

16 Wawancara guru kelas II, tanggal 18 Maret 2021 
pembelajaran. Sebagai salah satu bentuk efesiensi dan efektivitas implementasi kurikulum, yaitu dengan dimunculkannya sebagai model implementasi kurikulum. Model pembelajaran tematik merupakan salah satu model implementasi kurikulum yang dianjurkan pada tingkat satuan pendidikan sekolah dasar.

Model pembelajaran tematik pada hakikatnya merupakan suatu sistem pembelajaran yang memungkinkan siswa baik secara individual maupun kelompok aktif mencari, menggali, mengeksplorasi, dan menentukan konsep serta prinsipprinsip secara holistik, autentik dan berkesinambungan.

Pembelajaran tematik ini dirancang sesuai dengan usia anak pada sekolah dasar (7-11 tahun) yang mana kecenderungan belajarnya lebih keppada hal yang bersifat kongrit, integratif, dan hirarkis sehingga sangat cocok bila diterapkan pada pembelajaran di sekolah. Adapun pengelolaan kegiatan pembelajaran pada Kelas II b di MI As-Salam O'o Dompu dalam mata pelajaran dan pembiasaan dilakukan dengan menggunakan model pembelajaran masih terbilang semi tematik maksudnya pemishan antar mata pelajaran masih terlihat karena tematik murni yang pernah diterapkan kurang efektif dalam pelaksanaanya.

Adapun pembelajaran tematik hanya berlakuku pada kelas I,II,dan III sedangkan untuk kelas IV,V dan VI masih menggunakan KTSP. Sesuai dengan tahapan perkembangan anak yang masih melihat segala sesuatu sebagai suatu kebutuhan, pembelajaran yang menyajikan mata pelajaran secara terpisah akan menyebabkan kurang mengembangkan anak dan membuat kesulitan bagi peserta didik. ${ }^{17}$

Pentingnya pembelajaran tematik diterapkan karena siswa dapat memperoleh pengalam langsung dan terlatih untuk dapat menemukan sendiri berbagai pengetahuan yang dipelajar secara holistic, bermakna, autentik dan aktif. ${ }^{18}$ Apabila ditinjau dari aspek guru dan peserta didik tematik memiliki beberapa keuntungan. Keuntungan bagi guru antara lain adalah

a. Tersedia waktu lebih banyak untuk pembelajaran. Materi pembelajaran tidak dibatasi oleh jam pelajaran, melainkan dapat dilanjutkan sepanjang hari, mencakup berbagai mata pelajaran.

b. Guru dapat menghemat waktu karena mata pelajaran yang disajikan secara tematik dapat dipersiapkan sekaligus dan diberikan dalam dia atau tiga pertemuan, waktu selebihnya dapat digunakan untuk kegiatan remedial, pemantapan atau pengayaan.

c. Kompetensi dasar dapat dikembangkan lebih baik karena mengaitkan berbagai mata pelajaran dengan pengalaman pribadi dalam situasi nyata yang diikat dalam satu tema tertentu.

Sedangkan keuntungan pembelajaran tematik bagi peserta didik adalah sebagai berikut:

a. Peserta didik mudah memusatkan perhatian pada suatu tema tertentu karena materi disajikan dalam konteks tema yang jelas

17 Tritanto, Mengembangkan Model Pembelajaran Tematik, Jakarta: PT. Prestasi Pustakarya, 2011, hal 11.

18 Rusman, Model-Model Pembelajaran Mengembangkan Professional Guru, Jakarta: Rajawali Pers, 2011, hal 257. 
b. Peserta didik mampu mempelajari pengetahuan dan mengembangkan berbagai kompetensi dasar antar mata pelajaran dalam tema yang sama

c. Pembelajaran mampu meningkatkan pemahaman konseptual peserta didik terhadap tealitas sesuai dengan tingkat perkembangan intelektualnya.

d. Pembelajaran tematik memungkinkan peserta didik mampu mengeksplorasi pengetahuan melalui serangkaian proses kegiatan pembelajaran.

\section{Tahap Perencanaan Pelaksanaan Pembelajaran Tematik}

Dalam tahap perencanaan pembelajaran tematik yang perlu dilakukan adalah membuat perangkat pembelajaran yang meliputi kegiatan pemetaan, kompetensi dasar, indikator, pengembangan jaringan tema, pengembangan silabus, dan penyusunan rencana pembelajaran.

Konsep ini sudah diterapkan oleh guru Kelas II b MI As-Salam O'O Dompu. Perangkat pembelajaran yang dimiliki oleh guru kelas berupa kompetensi dasar, jaringan tema, analisis pecan efektif, program tahunan, program semester, silabus dan RPP. Perangkat pembelajaran tematik yang baik adalah dibuat oleh guru sendiri, karena gurulah yang mengetahui kondisi dan karakteristik siswanya.

Menentukan tema pembelajaran merupakan hal yang sangat penting dalam pembelajaran tematik, karena dengan tema itulah berbagai mata pelajaran dapat disatukan. Dalam menentukan tema juga harus mengikuti beberapa prinsip-prinsip penentuan tema yaitu :

1. Memperhatikan lingkungan terdekat dengan siswa

2. Tema dipilih dari yang termudah menuju yang sulit, dari yang sederhana menuju yang kompleks, dari yang konkret menuju yang abstrak.

3. Tema yang dipilih harus memungkinkan terjadinya proses berfikir pada diri siswa.

4. Ruang lingkup tema disesuaikan dengan usia dan perkembangan siswa termaksud minat, kebutuhan, dan kemampuannya.

Dari temuan di lapangan bahwa konsep ini sudah dilaksanakan, di dalam menentukan tema guru Kelas II b sudah menyesuaikan dengan minat dan kebutuhan siswa, tema yang ditetapkan berhubungan dengan kehidupan siswa sehari-hari, seperti keluarga, kegemaran, lingkungan dan lain-lain. Silabus merupakan penjabaran dari standar kompetensi, kompetensi dasar yang ingin dicapai dan pokok-pokok serta uraian materi yang perlu dipelajari siswa dalam rangka mencapai standard kompetensi dan kompetensi dasar dengan berisi tema, mata pelajaran, standard kompetensi, kompetensi dasar, materi pokok, kegiatan pembelajaran, indikator, penilaian, alokasi waktu dan sumber belajar yng dibuat secara terpisah. Sedangkan untuk keperluan pelaksanaan pembelajaran tematik perlu disusun rencana pembelajaran (RPP). Penyusunan rencana pembelajaran ini merupakan realisasi dari pengalaman belajar siswa yang telah ditetapkan dalam silabus pembelajaran.

\section{Tahap Pelaksanaan Pembelajaran Tematik}


Pelaksanaan proses pembelajaran tematik adalah kegitan berinteraksi dengan siswa dalam upaya menyajikan materi pembelajaran. Proses ini diperlukan kemampuan guru untuk mengelola suasana belajar menjadi aktif, kondusif, dan menyenangkan, sehingga siswa menjadi tertarik dan termotivasi dalam belajar. Dalam tahap pelaksanaan pembelajaran tematik diKelas II b guru sudah tampak memberikan bimbingan pada siswa, dan melakukan interaksi dengan siswa. Dari temuan di lapangan, bimbingan yang dilakukan oleh guru sudah baik, hal ini terlihat dari guru yang menjalankan sebagai fasilitator, pembelajaran walaupun dalam pelaksanaan belum menerapkan tematik murni. Hal ini sesuai dengan karakter pada pembelajaran tematik sebagai bagian dari pembelajaran terpadu. Pembelajaran terpadu sebagai suatu proses mempunyai beberapa karakteristik atau cirri-ciri yaitu holistik, otentik, bermakna dan aktif.

Pada pembelajaran guru Kelas II b sudah menggunakan metode berbasis pembelajaran aktif namun dalam pelaksanaannya hanya menggunakan dua sampai tiga metode saja. Hal ini kurang sesuai dengan apa yang diungkapkan oleh Abdul Munir, dkk bahwa penggunaan metode dalam pembelajaran tematik yang baik adalah multi metode. Yaitu memadukan beberapa metode dalam pembelajaran. Dengan multi metode akan tercipta berbagai variasi kegiatan, sehingga akan sesuai dengan karakteristik dari pembelajaran tematik. ${ }^{19}$

Berdasarkan temuan dilapangan, sumber belajar yang digunakan guru Kelas II b di MI As-Salam O’o Dompu adalah buku ajar yang berupa buku teks dan buku paket tematik. Kedua buku ini sangat dimanfaatkan oleh guru dan siswa sebagai sumber belajar yang utama. Buku penunjang yang sudah ada saat ini untuk masingmasing pelajaran masih dapat dipergunakan dalam diupayakan adanya buku suplemen khusus yang memuat bahan ajar yang terintegrasi untuk membantu siswa sejak dini emamhami berbagai ilmu pengetahuan. ${ }^{20}$

Dari temuan dilapangan, selama ini guru masih belum memanfaatkan sumber belajar yang ada pada lingkungan. Lingkungan yang dimaksud adalah lingkungan anak, misalnya lingkungan sekolah. Banyak keuntungan yang dapat diperoleh dari pemanfaatan sumber belajar dari lingkungan contohnya, siswa dapat memperoleh pengalaman langsung dari apa yang ia lihat, dengar, dan yang ia raba, perolehana konsep bukan dengan cara mengajar menghafal, tetapi melakukan sendiri. Akan tetapi guru hanya terpacu pada buku paket tematik.

\section{Tahap Penilaian Pembelajaran Tematik}

Penilaian merupakan serangkaian kegiatan untuk memperoleh, menganalisis, dan menafsirkan data tentang proses dan hasil belajar siswa yang dilakukan secara berkesinambungan, sehingga menjadi informasi yang bermakna dalam pengambilan keputusan. ${ }^{21}$

Dari hasil temuan peneliti di lapangan, guru Kelas II b di MI As-Salam O'o Dompu sudah melakukan penilaian dalam pembelajaran. Penilaian proses di lakukan

19 Abdul munir, dkk. Pedoman Pelaksanaan Pembelajaran Tematik, Jakarta: 2005, Direktorat Jendral Kelembangaan Agama Islam. Hal 13.

20 Rusman, Model-Model Pembelajaran Tematik

21 Tritanto, Model Pembelajaran Terpadu (Konsep, Strategi dan Implementasi Dalam KTSP), Jakarta: Bumi Askara, 2010. Hal 87 
pada saat proses belajar mengajar berlangsung. Penilaian proses yang dilakukan guru yang berupa pengamatan terhadap kegiatan-kegiatan siswa baik secara individual maupun kelompok. Apek-aspek yang diamati guru masih terbatas karena kegiatankegiatan dalam pembelajaran masih tampak kurang bervariasi. Dalam penilaian hasil guru menggunakan alat penilaian berupa tes. Tes digunakan untuk melaksanakan evaluasi berupa soal-soal yang dibuat oleh guru itu sendiri. Untuk memudahkan admisnistrasi, penilaian hasil dilakukan pada setiap mata pelajaran secara terpisah.

Acuan yang dilakukan oleh guru Kelas II b dalam melakukan penilaian adalah masih mengacu pada KKM yang telah ditetapkan dalam KTSP . dalam menetapkan KKM, sekolah perlu mempertimbangkan akademis siswa, kompleksitas indikator, dan daya dukung (guru dan sarana). Adapun ketuntasan belajar di MI As-Salam O'O Dompu sesuai dengan KKM yang ditetapkan pada KTSP yang buat oleh masingmasing sekolah

\section{Problematika Guru Dalam Mengimplementasikan Pembelajaran Tematik di MI As-Salam O'O Dompu}

Berdasarkan hasil penelitian yang diperoleh dilapangan, diketahui bahwa pelaksanaan pembelajaran tematik, khususnya pada guru Kelas II b mengalami berbagai problem. Secara garis besar problematika tersebut meliputi:

1. Pemahaman guru terhadap pelaksanaan pembelajaran tematik

2. Merencanakan pembelajaran tematik

3. Hambatan dalam melaksanakannya

Problematika tersebut ditunjukan bahwa guru Kelas II b di MI As-Salam O’O Dompu kurang mendapat informasi yang jelas tentang pembelajaran tematik. Hal ini juga sesuai dengan implikasi dari pembelajaran tematik bagi guru yaitu guru dituntut untuk kreatif dan memiliki jiwa inovatif. Selain itu selama ini masih kurang adanya sosialisasi dari pihak terkait (dinas pendidikan) tentang pembelajaran tematik. Sehingga didalam membuat perencanaan maupun didalam melaksanakan kegiatan dikelas maasih kurang Nampak seperti pembelajaran biasa (konvensional).

Adapun problematika dalam menerapkan tematik yang dialami oleh guru Kelas II b di MI As-Salam O'O Dompu, yaitu menyusun RPP. Kesulitan yang dialami oleh guru dalam menyusun RPP adalah menentukan rumusuan tujuan pembelajaran, dan menentukan media yang sesuai dengan tema. Dari temuan di lapangan, dapat diketahui bahwa selama ini guru masih kesulitan untuk menyajikan konsep dari berbagai mata pelajaran kedalam satu tema. Dalam menyajikan konsep tersebut guru masih cenderung menyajikan secara terpisah untuk masing-masing mata pelajaran. Hal ini mengacu pada penilaian yang masih dilakukan secara terpisah untuk setiap mata pelajaran.

Kesulitan dalam melaksanakan kegiatan yaitu menyajikan konsep dari berbagai mata pelajaran dalam satu tema menggunakan pendekatan PAKEM. Kesulitan dalam melaksanakan pembelajaran tematik yang dialami oleh guru Kelas II b adalah terbatasnya buku ajar, penerapan model pembelajaran tematik di sekolah dasar/MI menurut tersedianya bahan ajar yang memadai dan dapat memenuhi kebutuan pembelajaran yang memadai dan dapat memenuhi kebutuhan pembelajaran yang terintegrasi antar satu mata pelajaran dengan mata pelajaran lainnya. Dan sarana 
prasarana dalam kelas masih kurang memadai, pembelajaran tematik pada hakekatnya menekankan siswa baik secara individual maupun kelompok aktif mencari, menggali, dan menemukan konsep secara holistik dan otentik. Oleh karena itu dalam pelaksanaannya memerlukan saran prasana belajar.

\section{Upaya Guru Dalam Mengatasi Problematika Pengimplementasian di MI As- Salam O'o Dompu.}

Solusi yang ditempuh oleh guru Kelas II b meliputi solusi untuk mengatasi tingkat pemahaman guru problem dalam membuat perencanaan dan melaksanakan pembelajaran tematik. Solusi yang ditempuh untuk untuk mengatasi problematika tersebut dapat diketahui bahwa solusi tersebut meliputi diskusi dengan teman sejawat, membahas kegiatan dalam KKG dan mengikuti workshop.

Pendidikan dan pelatihan yang diikuti oleh guru-guru di MI As-salam O'o Dompu selama ini dalah pelatihan yang diselenggarakan oleh cabang Depag Kabupaten Dompu. Dengan mengikuti pendidikan dan pelatihan guru diharapkan dapat meningkatkan pemahaman tentang pembelajaran tematik. Apapbila guru dering mengikuti pendidikan dan pelatihan pemahaman guru khususnya tentang pembelajaran tematik akan lebuh baik. Selain itu adapun cara yang lebih baik yang dapat mengatasi problematika yang dialami oleh guru dalam pembelajaran tematik yaitu dengan mengikuti seminar atau workshop.

Komunikasi dengan orang tua juga dibutuhkan karena para orang tua juga ikut membantu dan memperhatikan dalam proses tingkat kemajuan belajar siswa. Penerapan model pembelajaran tematik di sekolah dasar/madrasah menuntut tersedianya bahan ajar yang memadai dan dapat memenuhi kebutuhan pembelajaran yang terintegritas antar satu mata pelajaran dengan mata pelajaran yang lainya.

Dengan adanya problematika tersebut bukan berarti guru tidak menerapkan pembelajaran tematik dengan maksimal dan sebaik-baiknya, melainkan problematika dapat dilakukan guru untuk membuktikan profesionalismenya. Tugas guru adalah sebagai motivator, mediator dan fasilitator pembelajaran, bukan mencurahkan dan mensuplai siswa dengan berbagai ilmu pengetahuan saja. Diakui bahwa berhasil atau tidaknya pelaksanaan pembelajaran tematik sangat dipengaruhi oleh kemampuan guru yang akan menerapkan dan mengaktualisasikan model pembelajaran tersebut. Disamping itu pelaksanaan pembelajaran tematik dalam kegiatan pembelajaran di sekolah selain tingkat pemahaman guru tentang pembelajaran tematik baik konseptual maupun secara praktikal, hal ini juga sangat dipengaruhi oleh dukungan sumber belajar dan sarana prasarana yang memadai.

Pembelajaran bukan semata-mata tanggung jawab guru akan tetapi merupakan tanggung jawab bersama antara kepala madrasah, wakil kepala sekolah bidang kurikulum, guru sehingga pembinaan terhadap komponen-komponen tersebut merupakan tuntutan yang harus dipenuhi dalam mengefektifkan pelaksanaan pembelajaran tematik.

\section{KESIMPULAN DAN SARAN [Garamond, 13 bold]}

Berdasarkan uraian latar belakang dan pembahasan di atas dapat disimpulkan bahwa: (1) Implementasi pembelajaran tematik di masa pandemi Covid-19 dilakukan 
tanpa mengabaikan administrasi Pendidikan seperti penggunaan RPP dalam pembelajaran. Pada prakteknya terdapat berbagai tantangan guru diantaranya adalah karena kebiasaan dan pemahaman guru dalam melaksanakan pembelajaran tematik masih minim, lebih-lebih di tengah pandemi covid 19 seperti perencanaan, pelaksanaan dan pengelolaan kelas serta evaluasi pembelajaran tematik. Adapun upaya guru dalam mengatasi berbagai persoalan diantaranya dilakukan dengan berbagai kegiatan seperti diskusi rutin antar guru dan mengikuti berbagai workshop kurikulum 2013.

\section{REFERENSI}

Ruslam, Ahmadi. Pengantar Pendidikan. Yogyakarta : Ar-Ruzz Media, 2016.

Depdiknas. Undang-undang Sistem Pendidikan. Jakarta: Eka Jaya, 2003.

Imam Barnadid, Dasar-Dasar Pendidikan. Bogor : Galia Indonesia, 2018.

Hasbullah, Dasar-Dasar Ilmu Pendidikan (Edisi Revisi). Jakarta: Raja Grafindo Persada, 2012.

Erwin, Widiosworo, 19 Kiat Sukses Motivasi Belajar Peserta Didik. Yogyakarta: Ar-Ruzz Media, 2015.

Sofian, Amri. Pengembangan Dan Model Pembelajaran Dalam Kurikulum 2013. Jakarta: Prestasi Putrakarya, 2013.

Trianto. Pengembangan Model Pembelajaran Tematik. Jakarta: Prestasi Pustakakarya, 2010.

Permendikbud Nomor : 4 Tahun 2020 tanggal 24 Maret 2020 tentang pelaksanaan kebijakan pendidikan dalam masa darurat penyebaran Coronavirus Disease (Covid19), surat edaran gubernur Nusa Tengaara Barat Nomor : 180/136/Kum tanggal 26 Maret 2020 tentang Pelaksanaan Kebijakan Dalam Masa Darurat penyebaran Covid-19.

Surat Edaran Nomor 360/90/BPBD/III/2021 tentang "Pelaksanaan kegiatan tatap muka tahun ajaran 2020/2021 di masa pandemic covid-19 di Kabupaten Dompu"

Sugiyono. Metode Penelitian Pendidikan Pendekatan Kualitatif, Kuantitatif, Dan R\&D. Bandung: Alfabeta, 2015.

Rusman. Model-Model Pembelajaran Mengembangkan Professional Guru. Jakarta: Rajawali Pers, 2011.

Abdul munir, dkk. Pedoman Pelaksanaan Pembelajaran Tematik, Jakarta: Direktorat Jendral Kelembangaan Agama Islam, 2005.

Trianto. Model Pembelajaran Terpadu (Konsep, Strategi dan Implementasi Dalam KTSP). Jakarta: Bumi Askara, 2010. 